$\xi=-1$

\title{
Analysing the effects of strategic assets on company success : an evidence in manufacturing company
}

\author{
Sarminah Samad ${ }^{1 *}$, Hazaz Abdullah Alsolami $^{2}$ \\ ${ }^{1}$ Department of Business Administration/CMBA-Research Centre, College of Business and Administration, \\ Princess Nourah Bint Abdulrahman University, KSA \\ ${ }^{2}$ Department of Saudi Air Navigation Services, General Authority of Civil Aviation, Jeddah, KSA \\ *Corresponding author E-mail: sarminasamad@gmail.com
}

\begin{abstract}
Manufacturing industry plays a significant role in the development of a nation. Thus, analyzing the factors influencing its success is profoundly needed. Scholars have identified strategic assets as a key factors that influence the success of manufacturing companies. This study examined the relationship between strategic assets on company success. 400 manufacturing companies in Malaysia have participated in the survey. A total of 299 usable questionnaires were analyzed using Smart Partial Least Squares (PLS). The results revealed that manufacturing companies should consider increasing their strategic assets to achieve superior success. This suggests that strategic assets are crucial towards improving company success. The results found that intangible assets have emerged as the most significant predictor that affect company success. The implications of this study and recommendations for future research are also discussed.
\end{abstract}

Keywords: Strategic Assets, Company Success

\section{Introduction}

The rapid changes in economy and technology have forced organizations to be more alert towards triggering events that may affect their business. The organizations need to identify the key drivers for the company success. Literature have highlighted the pivotal role of strategic assets in order to position business strategies and firm success [1]. While most literature have emphasized the importance of assets for company success, this idea is not well understood and research was scarcely done in Malaysian manufacturing companies. Therefore, analysis of strategic assets is vital to identify the critical factors of company success [2]. This analysis is profoundly pertinent to determine which strategic assets within the company is important. This study focuses the effects of tangible and intangible strategic assets and dynamic capability on company success.

Strategic assets have been frequently defined based on intangible and tangible assets, as postulated in resource based theory (RBT) [3]. Nevertheless, there is some inertia in this concept as it fails to address criticisms that have been posited by researchers pertaining to the dynamism of the assets. To extricate this issue, the dynamic capability theory was developed [4]. Furthermore, scholars have argued that tangible and intangible assets do not necessarily help in achieving competitive advantage without the existence of dynamic capabilities. The reason being dynamic capabilities will continuously create new business capabilities [4, 5]. Literature revealed a variety of contentions about the concept of strategic assets. However, scholars are in consensus that dynamic capabilities are conceptualized within the category of organizational strategic assets [6].

Abundant studies have linked the success of firms to strategic assets and competitive advantage [7]. However, most previous studies have epitomized strategic assets in terms of tangible and intangible assets [8]. Whereas some scholars have classified that dynamic capability is part of strategic assets. Currently, there is a dearth of studies that integrate strategic assets (tangible and intangible assets) with dynamic capabilities in manufacturing industry. Furthermore, only a limited amount of study in this topic is available in developing countries, particularly in Malaysia. Hence, we aim to provide empirical evidence on the effects of strategic assets in terms of tangible and intangible assets and dynamic capability on company success. We attained this aim through a quantitative and a cross-sectional study on the effects of strategic assets on company success across Malaysian manufacturing companies. We hope the study will uncover new managerial insights and contributes new knowledge to the existing theory.

The discussion of this paper is organized based on the following: Firstly, literature review related to strategic assets and company success are provided. This is followed by the methodology used and the presentation of findings, and data analysis from the selfadministered questionnaire of 299 managers to explore the link between strategic assets and company success. The evidence shows the relationship between strategic assets and company success. The final part highlights the conclusion, implications, and recommendations for further studies.

\section{Literature review}

\subsection{Company success}

Several theories in strategic management are associated with the success of a company such as profit-maximising and competitionbased theory, the resource-based theory, the survival-based theory, 
the human resource based theory, the agency theory, the contingency theory, knowledge based theory, and dynamic capability theory $[9,10]$. Company success has always been related to company performance, which the latter has been the concern of many managers and scholars. This is because company performance is the key criterion for evaluating its success, actions, and environments [11]. Though company performance is the central phenomenon in management studies, but it is rather complex and multidimensional. A sustained company performance is characterized by the ability to achieve superior market performance and financial performance. In other words, it indicates the ability of a company to create and achieve set goals and execute acceptable actions and outcomes. Meanwhile, success is referred to the attainment of goals and objectives in any segments of human life. In the business world, success signifies a crux of term in business management explicitly or implicitly and has been used as the major indicator to describe the difference in outcomes of company performance. Accordingly, in business studies, financial performance is denoted as the main indicator for company success. However [12] opined that business and company success could be interpreted in various perspectives, thus there is no universal concept of company success. Two main dimensions of success are commonly referred in existing literature; financial and non-financial, and short or long term [13]. Financial success could be in a form of business survival, profit, return on investment, and sales growth, whereas non-financial success could be in a form of satisfaction, service quality, and reputation. Two phenomena in business that are commonly shared by people are the characteristics of successful business and the ability of a company to perform better than its competitors. Hence, understanding the key factors in achieving company success has long been the concern of researchers and company management.

\subsection{Resource-based and dynamic capability theory}

Scholars have categorized assets into tangible and intangible aspects. Studies have also classified strategic assets based on: 1) tangible assets, e.g. equipment, finances, physical resources, and information technologies [14] 2) intangible assets, e.g. technology (patent and copyright), reputation, business resources, and human assets such as skills and motivation [15] and 3) dynamic capabilities [6]. Over the last couple of decades, Resource-based Theory (RBT) has been frequently applied to explain the importance of strategic assets as sources of competitive advantage to achieve company success [16]. The criteria of strategic assets which are attributed as valuable, rare, imperfectly imitable, and non-substitutable have been used by company to perform well and hence achieve success [10]. Strategic assets have been denoted as sources of superior firm profits [17].

The explanation of strategic assets based on RBT has been hampered by limitations and criticisms. RBT appeared to be unable to perfectly explain how and why certain companies outperform their competitors and are able to secure competitive advantage in dynamic and uncertain environments [18]. RBT only emphasizes the unique bundle of resources to create competitive advantage instead of company ability to deal with the rigidities created by organisational dependence [19]. Undeniably, a valuable asset is signified by the capability of the company to exploit business opportunities and face threats from the rivals. It was argued that the heterogeneous tangible and intangible assets explain the variations in company success, indicating the importance of capability to deal with business competition [3]. Thus theory of dynamic capability (DCT) was postulated as an alternative to RBT [4]. This theory explains in detail the utilization of assets for company performance. DCT emphasizes the importance of manipulating available assets and the capabilities to avoid rigidity [20]. The capability of a company to manage rigidity determines the success which consequently would propel competitive advantage if the internal resources are reconfigured [19].

Capability signifies the ability of a company to exploit its re- sources in terms of business processes and routines to ensure that the inputs could be turned into the desired outputs, e.g. through integration, learning and gain and reconfiguration [6]. Capability is functionally-based, which includes several types of capabilities, e.g. marketing capabilities and human resource capabilities. Capabilities can turn to become dynamic if they are constantly being changed and reconfigured to become more adaptive in unpredictable environments [2]. Capability consists of three important characteristics; competency, core competency and distinctive competency. Competency is a cross-functional mix and coordination of capabilities in a company. Core competency refers to the accumulation for competencies across divisions that will help the company to perform exceptionally. Contrary to this, distinctive competency could be secured when a company possesses superior competency compared to its rivals. Although arguments between intangible and tangible assets, and capabilities exist, [6] contended that these concepts are within the same category of strategic assets This is because dynamic capabilities are based on the usage of assets by a firm to ensure its success $[4,18]$. RBT explains how the unique collection of internal assets of a company are determined, while dynamic capabilities constitute the basis for developing strategies in order to create value. Deriving from these premises, we examined the effects of strategic assets based on the three constructs (tangible assets, intangible assets and dynamic capabilities) on company success.

\subsection{Factors affecting the company success}

A plethora of variation in the criteria for measuring company success are used in literature. Empirical studies documented two streams of thoughts pertaining to the factors that affect company success, which is firstly based on a determined set of constructs and secondly, based on the comprehensive and holistic constructs. Previous studies indicated that both tangible and intangible assets as well as the dynamic capabilities have significantly affected company success [16]. Another study also indicated a significant relationship between tangible assets of physical resources and technology with the success of firms in manufacturing sectors (trading and services) [21]. Physical assets are important aspects of strategic assets to achieve company success [14]. Information technology is also a valuable internal asset that could improve internal communication, enhance product design quality, reduce design cycle time, and lower product development cost [22]. Success in the manufacturing industry has also been influenced by strategic asset such as superior technology support [6]. This is parallel with the increasingly volatile and rapidly evolving technology that are highly demanded in the Malaysian manufacturing industry, as envisioned in vision 2020. Based on the preceding discussions, we hypothesize that: Tangible strategic assets significantly influence company success (H1).

The available intangible assets help firms to produce a market offering that has value in different market segments [23].Companies possessing assets that are superior over their rivals will perform better [24]. Empirical research converged the embedded knowledge in human capital and reputation as the intangible assets that are universally valuable and imperfectly imitable $[16,25]$. A study conducted in Malaysian industries found that human capital; a component of intellectual capital has a significant link with company performance [26]. Consistent to RBT, empirical evidence indicated that superior human capital lead to competitive advantage and a sustainable superior company success [12]. Human capital was found to be a pivotal factor in business and company successes [27]. Accordingly, in a longitudinal study of Swedish firms, it was found that education level and managerial competencies have significant effects on the success of companies in new product development [28]. Though intangible construct has been epitomized as prevalent for company success, it is evident that this model is not widely applied and tested in the Malaysian manufacturing industry. While human capital aspects such as knowledge, skills and abilities have been linked to company suc- 
cess, other scholars, have related company success to corporate reputation [29]. Corporate reputation is an asset that has a considerable value that helps in enhancing the expectation of customers pertaining to the offerings and performance of the company [30]. We propose reputation as an intangible factor that will also improve company success in Malaysian manufacturing companies. Realizing the importance of corporate reputation, we justify that this study is plausible and warranted since there is still a lack of theoretical and empirical evidence in the Malaysian manufacturing setting. Moreover, [15] echoed that reputation is a key asset for value creation, profitable growth, sustainable competitive performance, and the ability of a company to outperform its competitors. Thus, we propose the following hypothesis: Intangible strategic assets significantly influence company success (H2).

As recently cited in literature, company success has been linked to internal resources from tangible and intangible assets [31]. Only a limited amount of research, except for a few sporadic articles have included dynamic capabilities in their studies of strategic assets. Similarly, only a small volume of studies has considered the role of strategic assets (the combination of tangible and intangible assets with dynamic capabilities) on company success within Malaysian companies. Whereas, ignoring the importance role of these assets may lead to failure or the inability of companies in attaining superior successes [16]. Moreover, studies have revealed the profound effect of dynamic capabilities on company success [32]. A study found that dynamic capabilities are significantly related to company performance and success [33]. On the other hand, [6] have identified dynamic capabilities as the important determinant for financial performance of e-SMEs. Contrary to these findings, literature have shown insignificant relationship between dynamic capabilities and company success [18], indicating inconclusive research findings. Hence, we seek to answer the following hypothesis: Dynamic capabilities significantly influences company success $(\mathrm{H3})$.

\section{Material and methods}

This study employed a quantitative method based on primary data collected through self-administered questionnaire from a sample of population among manufacturing companies in Malaysia. The unit analysis is the managerial staff which was drawn from a sampling frame of Federal Manufacturing Malaysia (FMM) and Small Medium Enterprise Corporation (SMECorp). A total of 299 samples of respondents from a total population of 400 were selected based on random sampling, as suggested by [34, 35] with a valid return response rate of $74.75 \%$. The obtained data were analyzed using PLS-SEM analysis software version 3.0.

The questionnaires were divided into five parts, with demographic profiles in part one and the rest of parts 2 to 5 consist of items that measure strategic assets in terms of tangible assets, intangible assets, dynamic capabilities, and company success. Tangible assets consist of physical resources (4 items) and information technology (3 items), adapted from [14, 36]. Intangible assets which include human capital (6 items) and reputation (4 items) were adapted from [15, 37]. Dynamic capabilities with dimensions integration (5 items), learning and gain (4 items) and reconfiguration (3 items) were adapted from [6]. The dependent variable (company success) based on financial aspect (6 items) was adapted from ${ }^{6}$, while non-financial aspect (10 items) in terms of customer perspective, the internal process and the Learning and Growth was adapted from [38]. All dimensions were measured using seven-point Likert scale, ranging from 1 = strongly disagree to $7=$ strongly agree.

\section{Results and discussion}

From a total of 400 questionnaires distributed, 299 usable questionnaires were obtained, encompassing $33.44 \%$ females and $66.55 \%$ males. In terms of position, $39.46 \%$ were senior management staff, while $60.53 \%$ were lower managerial staff. About
$10.8 \%$ were respondents below 25 years old, followed by that of more than 25 to 35 years old ( $34.3 \%)$, more than 35 to 45 years old $(41.2 \%)$, and more than 45 years old $(13.7 \%)$. In terms of education, the majority $(63.5 \%)$ were bachelor holders, $3.3 \%$ masters holders and $33.10 \%$ with other professional qualifications. In terms of experience, $11.4 \%$ respondents have less than 2 years of experience, $41.5 \%$ with more than 2 to 5 years, $28.5 \%$ with more than 5 to 10 years, and $18.6 \%$ more than 10 years.

We used Partial Least Squares (PLS) software to analyse the research model based on the measurement and structural model [39]. Convergent validity (CV) was conducted, which encompasses three indicators namely factor loadings, average variance extracted (AVE), and composite reliability (CR) [40]. We also examined Cronbach's $\alpha$ values for all constructs, as well as discriminant validity (DV). The structural model was conducted to test the hypothesized relationship between the variables. The analysis used 5000 resample method to evaluate the loadings and significance of the path coefficient ${ }^{35}$. The main aim is to determine the level of significance of loadings, weights, and path coefficients.

Table 1 shows the result of measurement model. We analyzed measurement model based on the rule of thumbs of $>0.5$ for factor loadings and AVE, as well as $>0.70$ for composite reliability [35]. Meanwhile, the threshold value for Cronbach $\alpha$ is 0.5 [41]. Upon examination the values of each item and overall constructs, the analysis found that the values of factor loadings, AVE, CR, and Cronbach's $\alpha$, are above the minimum threshold. As depicted in Table 1, the overall items that exceed the minimum threshold values are Cronbach's $\alpha(0.744)$ and factors loading (0.829), AVE (0.623), and composite reliability (0.855), indicating appropriate and acceptable $\mathrm{CV}$. We performed discriminant analysis to examine the true distinction of each construct from each other. To determine DV, a comparison was done between the square root of AVE and correlations of the construct in the model. The existence of DV is proven when the correlation of other constructs are lesser than the AVE extracted [41].

Table 2 shows the discriminant validity of constructs which indicates the square root values that are greater than the correlation values of constructs in the row and column. The AVE threshold value is 0.50 [35], confirming that the discriminant validities in this study are accepted.

Table 3 shows the convergent validity and reliability which reveals the structural model. This analysis assesses the link between the hypothesized constructs in the model (See Table 4). The value of variance explained by $\mathrm{R}^{2}$ on endogenous constructs indicates the goodness of fit of the theoretical model and the significance of all path coefficients [42]. Both the path coefficients and $\mathrm{R}^{2}$ denote how authentic data supports the hypothesized model. The study found that the variance $\mathrm{R}^{2}$ of company success was 0.436 , indicating $43.6 \%$ of company success was explained by strategic assets (tangible assets, intangible assets, and dynamic capabilities).

Examining each construct in Table 4, it is confirmed that tangible assets are significantly related to company success $(b=0.250, p<$ $0.05)$, while intangible assets are significantly related to company success $(b=0.420, p<0.05)$, and dynamic capabilities are significantly related to company success $(b=0.326, p<0.05$. This data provide support for $\mathrm{H} 1, \mathrm{H} 2$ and $\mathrm{H} 3$ in the study. The present study also revealed that intangible assets emerge as the most important factor that influence company success, with the highest beta value followed by dynamic capabilities, and tangible assets. 
Table 1: Result of the Overall Measurement Model

\begin{tabular}{|c|c|c|c|c|c|}
\hline Construct & Item & Loadings & AVE & $\mathrm{CR}$ & Cronbach's $\alpha$ \\
\hline \multicolumn{6}{|l|}{ Strategic Assets } \\
\hline \multicolumn{6}{|l|}{ Tangible Assets (TA): } \\
\hline Physical Resources & $(\mathrm{PR}$ & 0.829 & 0.623 & 0.855 & 0.744 \\
\hline Information Technology & IT & 0.850 & & & \\
\hline \multicolumn{6}{|l|}{ Intangible Assets (IA): } \\
\hline Human capital & $\mathrm{HC}$ & 0.897 & 0.706 & 0.878 & 0.789 \\
\hline Reputation & $\mathrm{RP}$ & 0.867 & & & \\
\hline \multicolumn{6}{|l|}{ Dynamic Capabilities (DC): } \\
\hline Integration & IG & 0.880 & 0.818 & 0.931 & 0.889 \\
\hline Learning \& Gain & LG & 0.919 & & & \\
\hline Reconfiguration & $\mathrm{RG}$ & 0.915 & & & \\
\hline \multicolumn{6}{|l|}{ Company Success (CS): } \\
\hline Financial & $\mathrm{FN}$ & 0.848 & 0.701 & 0.903 & 0.855 \\
\hline Non-Financial & $\mathrm{NF}$ & 0.833 & & & \\
\hline
\end{tabular}

Table 2: Discriminant validity of constructs

\begin{tabular}{lcccc}
\hline Construct & TA & IA & DC & CP \\
\hline Tangible Assets (TA) & $\mathbf{0 . 7 9 8}$ & $\mathbf{0 . 8 0 2}$ & & \\
Intangible Assets (IA) & 0.583 & 0.577 & $\mathbf{0 . 8 8 9}$ & 0.373 \\
Dynamic Capabilities (DC) & 0.431 & 0.477 & $\mathbf{0 . 9 0 5}$ \\
Company Success (CS) & 0.525 & & \\
\hline
\end{tabular}

Table 3: Convergent validity and reliability

\begin{tabular}{lcccc}
\hline Construct & AVE & CR & $\mathrm{R}^{2}$ & Cronbach's $\alpha$ \\
\hline Tangible Assets & 0.623 & 0.855 & - & 0.744 \\
Intangible Assets & 0.706 & 0.878 & - & 0.789 \\
Dynamic Capabilities & 0.818 & 0.931 & - & 0.889 \\
Company Success & 0.701 & 0.903 & 0.436 & 0.855 \\
\hline
\end{tabular}

Table 4: Result of Hypotheses Testing

\begin{tabular}{llccrrr}
\hline Construct & Hypotheses & $\begin{array}{l}\text { Path } \\
\text { Coefficient }\end{array}$ & t-value & $\begin{array}{l}\text { Std } \\
\text { Error }\end{array}$ & P-Value & Decision \\
\hline TA-> CS & H1 & 0.250 & 0.056 & 4.434 & 0.000 & Supported \\
IA -> CS & H2 & 0.420 & 0.060 & 3.616 & 0.000 & Supported \\
DC -> CS & H3 & 0.326 & 0.040 & 3.769 & 0.000 & Supported
\end{tabular}

Notes:*p<0.05

\section{Conclusion}

The main aim of the study was to examine the effects of strategic assets; tangible assets, intangible assets and dynamic capabilities on company success. The study revealed that strategic assets in terms of intangible and tangible assets, as reflected in RBV and dynamic capabilities have been identified as factors that significantly affect company performance. These findings are parallel to previous studies by $[43,44,45,46]$. The most pertinent contribution to the body of knowledge is the substantial influence of intangible assets on company performance. These results are consistent with that stated by [31, 47], whom suggested that intangible assets in terms of human capital and reputation are the key factors that contribute towards the competitive advantage and success of a company. The findings indicate that intangible assets are gaining popularity and it is proven that in some instances, these assets exceed the value of tangible assets [48]. The findings in this study offer an elaboration of the well-cited theory of RBT and DCT which indicate the robustness of the theories on a sample involving managers in Malaysian manufacturing companies. Its most important contribution to the literature lies with the incorporation of dynamic capability into the strategic assets and their effects on company success. Undoubtedly, these factors are pertinent to company success, particularly in Malaysian manufacturing companies. Thus, focus should be given by management of manufacturing company on the influence and importance of strategic assets to achieve superior company success.

However, this study is limited, firstly due to its less comprehensive framework. The framework only includes three constructs (tangible and intangible assets, and dynamic capabilities). Other variables could be included in the model which may provide more powerful explanatory factors on company success. Secondly, the study did not consider a qualitative approach which may offer additional answers to the unaddressed salient points. However, the findings of this study undeniably validate previous research findings and serve as a new contribution, particularly in Malaysian manufacturing companies. Future studies may explore different settings and or various approaches of research.

\section{References}

[1] Choonwoo L, Kuunhmook L \& Johannes MP (2001), Strategic Management Journal 22, 615.

[2] Wheen TL, Hunger D, Hoffman AN \& Bamford C (2015), 
Strategic management and business policy: Globalization, Innovation and Sustainability, Pearson Education Limited, USA.

[3] Barney BJ (2001), Journal of Management 27, 643

[4] Teece DJ, Pisano G \& Shuen A (1997), A, Strategic Management Journal 18, 509.

[5] Leornard-Barton D (1992), Strategic Managemnet Journal 12, 111.

[6] Schlemmer F \& Webb B (2004), Electronic Markets 16, 371.

[7] Joseph EL, Isaac O, Thomas G \& Peter M (2017), International Academic Journal of Human Resource and Business Administration 2, 1.

[8] Leopoldo JG, Barrales-Molina V \& Hale K (2017), International Journal of Operations \& Production Management 38, 43.

[9] David F (2012), Strategic management: concepts and cases, New Jersey, Prentice Hall.

[10] Samad S, Yusuf SYM, Ahmed WA \& Yakub MA (2015), Australian Journal of Basic and Applied Sciences 9, 94.

[11] Asrol M, Marimin \& Machfud (2017), International Journal Supply Chain Management 6, 8 .

[12] Samad S (2013), International Journal of Trade, Economics and Finance 4, 393-399.

[13] Yakubu I, Alhassan MM \& Fuseini AA (2017), European Journal of Accounting and Finance Research 5, 68.

[14] Konnur BA \& Hundekar AL (2012), IOSR Journal of Mechanical and Civil Engineering, 324.

[15] Marcellis-Warin ND \& Teodoresco S (2017), Corporate Reputation: Is your most strategic asset at risk? [Internet] December 2017. Available from: file://C:/Users/User/Documents/Downloads/Corporate_Reputa tion_Is_Your_Most_Strategic_Asset_.pdf

[16] Coff RW (1997), Academy of Management Review 22, 374.

[17] Justus MK \& James K (2017), Journal of Business and Economic Development 2, 140 .

[18] Eisenhardt KM \& Martin J (2000), Dynamic capabilities: What are they?. Strategic Management Journal 21, 1105.

[19] Vergne JP \& Durand R (2011), Organization Studies 32, 365.

[20] Helfat CE, Finkelstein S, Mitchell W, Peteraf MA, Singh, D.J. Teece H (2007), Dynamic capabilities: Understanding strategic change in organizations, Blackwell, London.

[21] Inmyxai S \& Takahashi Y (2009), Journal of Indian Business Research 12, 163.

[22] Amoah-mensah A (2013), International Journal of Business and Social Research 3, 106.

[23] Hunt SD \& Morgan RM (1996), Journal of Marketing 60, 107.

[24] Samad S, Yusuf SYM, Masoud YAH \& Ahmed AW (2017), Research Journal of Applied Sciences 12, 37.

[25] Samad S Aziz NNA, Jaidi J \& Masoud Y (2016), International Business Management 10, 4163.

[26] Crook TR, Samuel YT, James GC, David JW \& David JK (2011), Journal of Applied Psychology 96, 443.

[27] Subramaniam M \& Youndt MA (2005), Academy of Management Journal 48, 450.

[28] McKelvie A \& Davidsson P (2009), British Journal of Management 20,63.

[29] George OJ, Owoyemi O \& Onakala U (2012), International Journal of Business Administration 3, 1.

[30] Lwanzo JL (2017), International Journal of Business and Management $12,149$.

[31] Barney JB (2002), Gaining and sustaining competitive advantage, Prentice-Hall, NJ

[32] Morgan N, Vorhies D \& Mason C (2009), Strategic Management Journal 30, 909.

[33] Roberts N \& Grover V (2011), Journal of Business Research 64.

[34] Krejcie RV \& Morgan DW (1970), Educational \& Psychological Measurement 30, 610.

[35] Hair JF, Hult GTM, Ringle CM \& Sarstedt M (2014), Primer on partial least squares structural equation modeling (PLSSEM), Sage Publication, Los Angeles.

[36] Kim MK \& Jee K (2007), ETRI Journal 29, 497.

[37] Memon AH, Rahman IA, Asmi A \& Azis A (2012), International Journal of Advances in Applied Sciences 1, 45.

[38] Kaplan RS \& Norton DP (2006), The balanced scorecard: Translating strategy into Action, Harvard Business School Press, Boston MA, USA.

[39] Ringle CM, Wende S \& Becker JM (2017), Partial Least Square. [Internet] December 2017. Available from URL: http://www.smartpls.de/documentation/partial-least-squares- algorithm

[40] Anderson JC \& Gerbing DW (1988), Psychological Bulletin 103,411

[41] Fornell C \& Larcker DF (1981), Journal of Marketing Research $18,39$.

[42] Chin WW (2010), Handbook of partial least squares, Springer hand book of computational, Heidelberg: Springer-Verlag, Berlin.

[43] Isik Z, Arditi D, Dikmen I (2010), Journal of Management in Engineering ASCE 26, 9.

[44] Lin Y \& Wu LY (2014), Exploring the role of dynamic capabilities in firm performance under the Resource-Based View framework, Journal of Business Research. 67, 407 - 413.

[45] Cox A, Higgins T \& Speckesser S (2011), Management practices and sustainable organizational performance: An Analysis of the European Company Survey' 2009, European Foundation for the Improvement of Living and Working Conditions, Dublin.

[46] Andersen J (2011), Management Decision 49, 87.

[47] Aziz NNA \& Samad S (2016), Procedia Economics and Finance, 35, 256-266.

[48] Teixeira J, Petri SM \& Marques TO (2012), Revista de Contabilidade do Mestrado em Ciências Contábeis da UERJ 17, 45. 